\title{
THE EFFECT OF DIETARY OILS AND HYDROLYZED COCONUT OIL ON MINERALS ABSORPTION IN RATS
}

\author{
LINDA MARGATA ${ }^{1 *}$, JANSEN SILALAHI ${ }^{1}$, URIP HARAHAP ${ }^{2}$, DENNY SATRIA ${ }^{3}$ \\ ${ }^{1}$ Department of Pharmaceutical Chemistry, Faculty of Pharmacy, University of Sumatera Utara, Medan, Indonesia. ${ }^{2}$ Department of \\ Pharmacology, Faculty of Pharmacy, University of Sumatera Utara, Medan, Indonesia. ${ }^{3}$ Department of Pharmaceutical Biology, Faculty of \\ Pharmacy, University of Sumatera Utara, Medan, Indonesia. Email: lindamargata@hotmail.com
}

Received: 16 June 2017, Revised and Accepted: 09 October 2017

\section{ABSTRACT}

Objective: The objective of this study was to investigate the effect of coconut oil (virgin coconut oil; VCO), corn oil, palm oil, and hydrolyzed VCO (HVCO) on minerals (calcium and magnesium) absorption in rats.

Methods: The oils used were corn oil, palm oil, VCO, and HVCO. VCO hydrolysis was done using lipase from Rhizomucor miehei (active on sn-1,3 position). The effect of oils and HVCO on minerals absorption was carried out on 25 male rats, weighing approximately $150-200 \mathrm{~g}$. Rats were housed in air-conditioned room at $22-25^{\circ} \mathrm{C}$, under 12 -light/dark cycle, fed on basal diet and tap water ad libitum. After 1-week acclimatization, rats were given oils and HVCO for 21 days. The effect of oils on the minerals absorption were determined over the 4-day metabolic balance study. Mineral concentrations in diet, feces, urine, and serum were measured using atomic absorption spectrometry. Minerals absorption are expressed as apparent minerals absorption, apparent minerals absorption rate, and apparent minerals balance.

Results: Calcium absorption in rats given with VCO, corn oil, palm oil, and HVCO is $47.09 \%, 45.46 \%, 44.48 \%$, and $49.33 \%$, respectively, whereas, magnesium absorption in rats given with VCO, corn oil, palm oil, and HVCO is $34.87 \%, 32.08 \%, 29.39 \%$, and $37.11 \%$, respectively. The results of this study show that minerals absorption in rats given with dietary oils is significantly lower than the control group $51.79 \%$ for calcium and $42.34 \%$ for magnesium). Mineral absorption in rats given with HVCO results in the highest rate of all rats given with the other oils tested.

Conclusion: Corn oil and palm oil, which belong to the long chain triglycerides oil, lower calcium, and magnesium absorption more significantly than VCO as a medium chain triglyceride oil does. HVCO results in significantly higher calcium and magnesium absorption compared to non-HVCO.

Keywords: Virgin coconut oil, Enzymatic hydrolysis, Rhizomucor miehei, Calcium, Magnesium, Absorption.

(c) 2018 The Authors. Published by Innovare Academic Sciences Pvt Ltd. This is an open access article under the CC BY license (http://creativecommons. org/licenses/by/4. 0/) DOI: http://dx.doi.org/10.22159/ajpcr.2018.v11i1.20687

\section{INTRODUCTION}

Minerals are classified as macrominerals and microminerals. Our bodies need more than $100 \mathrm{mg}$ macrominerals per day and $<100 \mathrm{mg}$ microminerals per day. Macrominerals include sodium, potassium, calcium, phosphorous and magnesium, while microminerals include ferrous, iodine, zinc and copper. Minerals play important roles in cells, tissues, organs, or overall body function. Low intake of these nutrients can be harmful. Calcium and magnesium are found in dairy products, vegetables and nuts [1-4].

More than $99 \%$ of total calcium in the body are found in bones and teeth, where calcium acts as the structural part, and the other $1 \%$ functions in the metabolism as a signal for a vital physiological process such as vascular contraction, blood coagulation, muscle contraction, and nerve transmission. Low intake of calcium is related to the increased risk of osteoporosis, nefrolitiasis (kidney stones), colorectal cancer, hypertension, stroke, coronary vascular disease, insulin resistance, and obesity $[2,4,5]$.

Magnesium is the fourth and the second most abundant cation in the body and intracellular fluid, respectively. Magnesium is a cofactor of 350 cellular enzymes that involve in energy metabolism. Magnesium is also involved in protein and nucleic acid synthesis, normal vascular function, insulin sensitivity, nerve impulses transmission, body temperature regulation, detoxification, and formation of healthy bones and teeth. Magnesium deficiency is associated with endothelial dysfunction, increased vascular reaction, increased circulating C-reactive protein, and decreased insulin sensitivity. Insufficient intake of magnesium is known to be involved in hypertension, coronary heart disease, Type 2 diabetes mellitus, and metabolic syndrome [2,4-7].

In the intestine, calcium and magnesium can interact with some food components causing disruption in their absorption. Those food components include oxalic acid, phytic acid, dietary fiber, and fat. Fatty acids, mainly from the hydrolyzed long-chain triglycerides (LCTs), can react with calcium and magnesium in the intestine to form insoluble salts. These salts are unable to be absorbed, and hence, excreted through the feces [8-10].

Coconut oil and virgin coconut oil (VCO), which composed mainly of medium chain triglyceride (MCT), are hydrolyzed rapidly in the mouth and stomach, while oils or fats composed of LCT are hydrolyzed slowly in the small intestine into long chain fatty acids (LCFAs). The products of hydrolyzed MCT, which are monoacylglycerol and medium chain fatty acids, are quickly absorbed through gastrointestinal mucous and then enter the circulation through the portal vein and directly to the liver $[11,12]$.

Rezq et al. reported the difference in calcium absorption influenced by some dietary oils and fats, soybean oil, corn oil, palm oil, olive oil, sunflower seed oil, butter, animal fat, and margarine [13]. Tadayyon and Lutwak also reported that there were differences in calcium and magnesium absorption affected by some triglycerides such as triolein, tripalmitin, and tristearin [14]. However, a study on the effect of hydrolyzed oil on calcium and magnesium absorption has not been reported. Therefore, the objective of this work was to study the effect of some dietary oils and hydrolyzed oil on calcium and magnesium 
absorption in rats. Oils used in this study were VCO, LCT oils which include palm oil (saturated oil), and corn oil (unsaturated oil). Hydrolysis of oil was done for VCO using lipase from Rhizomucor miehei which is active on sn-1,3 position in triglyceride molecule.

\section{MATERIALS AND METHODS}

\section{Materials}

VCO (Palem Mustika ${ }^{\circledR}$, Indonesia), palm oil (Bimoli ${ }^{\circledR}$, Indonesia), corn oil (Tropicana Slim ${ }^{\circledR}$, Indonesia), lipase from R. miehei 200 U/g(Strem Chemicals, Inc., US), buffer tris, sodium hydroxide, concentrated hydrochloric acid, distilled water, n-hexane, sodium sulfate anhydrous, potassium hydrogen phthalate, phenolphtalein, ethanol, and demineralized water were used. All chemicals and reagents used in this work were of analytical grade.

\section{Enzymatic hydrolysis of VCO}

Preliminary study of enzymatic hydrolysis was done to determine the optimum hydrolysis condition which was tested at several temperatures $\left(40^{\circ} \mathrm{C}\right.$ and $\left.50^{\circ} \mathrm{C}\right)$ and $\mathrm{pH}(7,8,10)$ for $8 \mathrm{~h}$. To obtain the best incubation period, VCO hydrolysis was done for $14 \mathrm{~h}$ with every $2 \mathrm{~h}$ of acid value determination. The best incubation period was indicated by the constant acid value obtained during the time of hydrolysis $(0-14 \mathrm{~h})[15]$.

$30 \mathrm{~g}$ of oil was weighed into $250 \mathrm{ml}$ Erlenmeyer flask, and then, $30 \mathrm{ml}$ distilled water, $12.5 \mathrm{ml} 0.063 \mathrm{M} \mathrm{CaCl}_{2}, 25 \mathrm{ml}$ buffer Tris- $\mathrm{HCl} 1 \mathrm{M} \mathrm{pH} 8$, and $3 \mathrm{ml}$ lipase $R$. miehei were added. The mixture was made 8 times in 8 separated Erlenmeyer flasks. All mixtures were stirred at $200 \mathrm{rpm}$ for $10 \mathrm{~min}$ of every $1 \mathrm{~h}$ incubation time. Each mixture was incubated at $50^{\circ} \mathrm{C}$ with various incubation time of $0,2,4,6,8,10,12$, and $14 \mathrm{~h}[14,16]$. At the end of each mixture's incubation time, the mixture was transferred into the separating funnel, and then, $50 \mathrm{ml} \mathrm{n}$-hexane was added, and extraction was done. The mixture was allowed to stand for some time until two layers were formed. The upper layer (n-hexane fraction) was separated as the first extract, while the bottom layer (water fraction) was extracted again with $50 \mathrm{ml} \mathrm{n}$-hexanes above and separated as the second extract. The first and the second extracts were mixed, and then, $250 \mathrm{~g}$ sodium sulfate anhydrous was added to absorb the water residue. The combined extract was allowed to stand for $15 \mathrm{~min}$, filtered, and the $\mathrm{n}$-hexane was evaporated using the water bath [15-18].

Hydrolyzed VCO (HVCO) incubated for $0,2,4,6,8,10,12$, and $14 \mathrm{~h}$ were labeled and their acid values were determined. HVCO with constant acid value [18] was then used to test its effect on calcium and magnesium absorption in rats.

\section{Acid value determination}

$5 \mathrm{~g}$ of HVCO was weighed and transferred into $250 \mathrm{ml}$ Erlenmeyer flask. $25 \mathrm{~mL}$ of neutral ethanol $90 \%$ was added and then heated for $10 \mathrm{~min}$ in a water bath while being stirred, then 3-5 drops of phenolphthalein were added into this solution. Titration was done with $0.1 \mathrm{~N} \mathrm{NaOH}$ until the solution turned pink (color did not change for $15 \mathrm{~min}$ ). The acid value and free fatty acid (FFA) percentage of HVCO were calculated using the following equation [15-20]:

a. Acid value

$$
\text { Acidvalue }=\frac{A \times \mathrm{N} \times \mathrm{BMNaOH}}{\mathrm{G}}
$$

Where,

$\mathrm{A}=\mathrm{NaOH}$ solution volume $(\mathrm{ml})$

$\mathrm{N}=$ Normality of $\mathrm{NaOH}$ solution

$\mathrm{G}=$ Sample mass $(\mathrm{g})$

Molecular weight of $\mathrm{NaOH}=40 \mathrm{~g} / \mathrm{mol}$

Acid value expressed as $\mathrm{mg} \mathrm{NaOH/g}$ oil was then converted to mg $\mathrm{KOH} / \mathrm{g}$ oil. b. Percentage of FFA

$$
\mathrm{CFFA}(\mathrm{wt} \%)=\frac{\mathrm{VNaOH} \times \mathrm{MNaOH} \times \mathrm{MMFFA}}{10 \times \mathrm{Ms}}
$$

Where,

CFFA=Content of free fatty acid (wt\%)

$\mathrm{VNaOH}=\mathrm{NaOH}$ solution volume $(\mathrm{ml})$

$\mathrm{MNaOH}=$ Molarity of $\mathrm{NaOH}$ solution $(\mathrm{mol} / \mathrm{L})$

MMFFA=Average molar mass of fatty acids $(200.32 \mathrm{~g} / \mathrm{mol})$

Ms=Sample mass (g)

\section{Experimental design}

The experiment was carried out on 25 male rats, weighing approximately $150-200$ g. Rats were housed in an air-conditioned room at $22-25^{\circ} \mathrm{C}$, under 12-light/dark cycle, fed on basal diet and tap water ad libitum. Animals were acclimatized for 1 week before starting the experiment. The protocol was approved by the Animal Research Ethics Committees of the Faculty of Mathematics and Natural Sciences, University of Sumatera Utara, Indonesia (bearing number: 881/KEPH-FMIPA/2016).

After acclimatization period, rats were divided into five groups with five animals each and were given as follows: (1) Without oil (control group), (2) $2 \mathrm{ml} / \mathrm{kg}$ body weight of VCO, (3) $2 \mathrm{ml} / \mathrm{kg}$ body weight of palm oil, (4) $2 \mathrm{ml} / \mathrm{kg}$ body weight of corn oil, and (5) $2 \mathrm{ml} / \mathrm{kg}$ body weight of HVCO, for 21 days. In the last week of experimental period (day 15-21), rats were housed in 25 individual metabolic cages containing a gridfloor and a facility for separate collection of feces and urine. Rats were acclimatized in the new environment for 2 days before the beginning of 4 days metabolic study. During the 4-day metabolic balance study period, each rat was given $7 \mathrm{~g} /$ day basal diet, so all of them consumed all the diet. Urine and fecal samples $(24 \mathrm{~h})$ from each animal were collected, and the volume of urine was recorded. Portions of the urine samples were acidified with $12 \mathrm{~N} \mathrm{HCl}$ about $3 \%$ of its volume and stored at $221-20^{\circ} \mathrm{C}$ until required for analysis $[13,21]$.

\section{Quantitative Analysis of Calcium and Magnesium in Samples}

Calcium calibration curve was prepared from standard solutions with the concentration of $0,2,4,6,8$, and $10 \mathrm{ppm}$, while magnesium calibration curve was prepared from standard solutions with the concentration of 0 , $0.2,0.4,0.6,0.8$, and $1 \mathrm{ppm}$. Each standard solution contains lanthanum chloride $1 \%$ and an aqueous solution containing lanthanum chloride $1 \%$ was used as blank. Calcium and magnesium in standard solutions were measured using atomic absorption spectrometry (AAS) at the wavelength of $422.7 \mathrm{~nm}$ and $285.2 \mathrm{~nm}$, respectively [22,23]. Calibration curves prepared were linear with the correlation coefficient of 0.9998 and 0.9995 for calcium and magnesium, respectively. The regression equation for calcium was $\mathrm{Y}=0.0722 \times+0.0061$, while for magnesium was $\mathrm{Y}=0.9791 \times+0.01565$.

The diet and fecal samples were ash-dried at $700^{\circ} \mathrm{C}$ for $12 \mathrm{~h}$ and then solubilized with $6 \mathrm{~N} \mathrm{HCl}$ solution. Diet, fecal, and urine samples were then diluted with an aqueous solution of lanthanum chloride $1 \% \mathrm{w} / \mathrm{v}$. Calcium and magnesium content in diet consumed, feces, and urine excreted per day were measured using AAS as the procedure mentioned above and calculated using the following equations [13,21-23]

$$
\text { Ca or Mg intake }(\mathrm{mg} / \mathrm{day})=\frac{\mathrm{X} \times \mathrm{V} \times \mathrm{DF}}{\mathrm{Ws}}
$$

Fecal Ca or Mg (mg/day) $=\mathrm{X} \times \mathrm{V} \times \mathrm{DF}$

$$
\text { Urinary Ca or } \mathrm{Mg}(\mathrm{mg} / \text { day })=\frac{\mathrm{X} \times \mathrm{V} \times \mathrm{DF}}{\mathrm{Vs}} \times \mathrm{Vu}
$$

Where,

$\mathrm{X}=$ Concentration of the diluted sample $(\mu \mathrm{g} / \mathrm{ml})$

$\mathrm{V}=$ Volume of the dilution $(\mathrm{ml})$ 
$\mathrm{DF}=$ Dilution factor (250 for diet and fecal sample; 1 for urine sample) Ws $=$ Weight of the sample $(7 \mathrm{~g})$

Vs=Volume of the measured sample $(\mathrm{ml})$

$\mathrm{Vu}=$ Volume of the urine collected $(\mathrm{ml})$.

Apparent absorption, apparent absorption rate, and apparent balance of each mineral (calcium or magnesium) were calculated using the following equations [13].

Apparent Ca or Mg absorption (mg/day) = Ca or Mg intake in diet-fecal Ca or Mg

Apparent Ca or Mg absorption rate (\%) $=\frac{\text { Ca or Mg absorption }}{\text { Ca or Mg intake in diet }} \times 100$

Apparent Ca or Mg balance (mg/day) = Ca or Mg intake in diet-(fecal Ca or Mg+urinary Ca or Mg).

At the last day of experimental period, rats were fasted for 12 $\mathrm{h}$ and sacrificed. Blood was drawn directly from the heart and centrifuged at $3000 \mathrm{rpm}$ for $15 \mathrm{~min}$ to obtain serum (supernatant). Serum $(0.5 \mathrm{ml})$ was diluted with an aqueous solution of lanthanum chloride $1 \% \mathrm{w} / \mathrm{v}$. Calcium and magnesium concentration $(\mathrm{mg} / \mathrm{dl})$ in serum were measured using AAS and calculated using the following equation $[13,14,23]$ :

$$
\text { Serum Ca or Mg }(\mathrm{mg} / \mathrm{dl})=\frac{\mathrm{X} \times \mathrm{V} \times \mathrm{DF}}{\mathrm{Vs} \times 10}
$$

Where

$\mathrm{X}=$ Concentration of the diluted sample $(\mu \mathrm{g} / \mathrm{ml})$

$\mathrm{V}=$ Volume of the dilution $(\mathrm{ml})$

$\mathrm{DF}=$ Dilution factor (1)

Vs=Volume of the sample $(\mathrm{ml})$.

\section{RESULTS AND DISCUSSION}

Optimum condition of VCO enzymatic hydrolysis

VCO enzymatic hydrolysis was done using lipase from $R$. miehei which is specific for acyl groups at sn-1 and sn-2 position in triglyceride molecule. In this study, the optimum condition for VCO enzymatic hydrolysis was done at several temperatures and $\mathrm{pH}$ [24]. To determine the optimum temperature $\left(40^{\circ} \mathrm{C}\right.$ or $\left.50^{\circ} \mathrm{C}\right)$, hydrolysis was done at $\mathrm{pH} 8$ and incubation time of $8 \mathrm{~h}$. Acid value and \%FFA are shown in Table 1.

Acid value and \%FFA of VCO hydrolyzed at $50^{\circ} \mathrm{C}$ are higher than VCO hydrolyzed at $40^{\circ} \mathrm{C}$. This indicates that lipase from $R$. miehei is more active at $50^{\circ} \mathrm{C}$. At temperature of $50^{\circ} \mathrm{C}$, this enzyme hydrolyzes fatty acids on sn- 1 and sn- 3 position in triglyceride molecule which generates two FFA and one 2-monoglyceride. From Table 1, it is shown

Table 1: Effect of temperature on VCO enzymatic hydrolysis

\begin{tabular}{lcc}
\hline Temperature & Acid value (mg KOH/g oil) $\mathbf{n}=\mathbf{3}$ & FFA (\%) $\mathbf{n}=\mathbf{3}$ \\
\hline $40^{\circ} \mathrm{C}$ & $83.29 \pm 0.12^{\mathrm{a}}$ & $29.79 \pm 0.05^{\mathrm{a}}$ \\
$50^{\circ} \mathrm{C}$ & $126.11 \pm 0.39^{\mathrm{b}}$ & $45.33 \pm 1.82^{\mathrm{b}}$ \\
\hline \multicolumn{2}{l}{ Means \pm SE in each column with different superscript letters differ significantly } \\
at $\mathrm{p}<0.05$. VCO: Virgin coconut oil
\end{tabular}

Table 2: Effect of pH on VCO enzymatic hydrolysis

\begin{tabular}{lll}
\hline $\mathbf{p H}$ & Acid value $(\mathbf{m g ~ K O H} / \mathbf{g}$ oil) $\mathbf{n}=\mathbf{3}$ & FFA $(\%) \mathbf{n}=\mathbf{3}$ \\
\hline 7 & $91.3438 \pm 0.4114^{\mathrm{a}}$ & $32.68 \pm 0.14^{\mathrm{a}}$ \\
8 & $126.1098 \pm 0.3931^{\mathrm{b}}$ & $45.33 \pm 1.82^{\mathrm{b}}$ \\
10 & $126.1798 \pm 0.1329^{\mathrm{b}}$ & $45.14 \pm 0.05^{\mathrm{b}}$ \\
\hline
\end{tabular}

Means $\pm S E$ in each column with different superscript letters differ significantly at $\mathrm{p}<0.05$. VCO: Virgin coconut oil that the optimum temperature for enzymatic hydrolysis is $50^{\circ} \mathrm{C}$. Hence, to determine the optimum $\mathrm{pH}(7,8$ or 10$)$, hydrolysis was done at $50^{\circ} \mathrm{C}$ and incubation time of $8 \mathrm{~h}$. Effect of $\mathrm{pH}$ on acid value and \%FFA of HVCO is shown in Table 2.

From Table 2, it is shown that the lowest acid value and \%FFA are obtained at $\mathrm{pH} 7$ which are $91.34 \mathrm{Mg} \mathrm{KOH} / \mathrm{g}$ oil and $32.68 \%$, respectively, while the acid value and \%FFA obtained at $\mathrm{pH} 8$ and 10 are not significantly different, and hence, the hydrolysis VCO was done at $\mathrm{pH} 8$.

\section{Optimum incubation time of VCO enzymatic hydrolysis}

Enzymatic hydrolysis of VCO was carried out for $14 \mathrm{~h}$, and acid value was determined in every $2 \mathrm{~h}$ of incubation time. The optimum incubation time indicated by the constant acid value obtained, after which there is no more FFA elevation because every triglyceride molecules from VCO has been hydrolyzed by lipase from $R$. miehei specifically at sn-1 and sn-3 position. Acid value determines the amount of FFA in fats or oils. It is defined as mg KOH used to neutralize FFA contained in $1 \mathrm{~g}$ of fats or oils. VCO enzymatic hydrolysis results in two FFA and one 2-monoglyceride from one triglyceride molecule contained in VCO $[15,19]$. The results show that there is an increasing acid value from 0 to $14 \mathrm{~h}$ incubation time, while constant acid value was obtained after $10 \mathrm{~h}$ of incubation time. This indicates that FFAs are not increasing significantly anymore after $10 \mathrm{~h}$ of incubation time. Acid value and FFA (\%) obtained from various incubation time are shown at Table 3 and Fig. 1.

Lipase (triacylglycerol acylhydrolases) catalyzes the hydrolysis and synthesis of esters formed from glycerol and fatty acids. Lipase is activated only when adsorbed to an oil-water interface. Commercially useful lipases are usually obtained from microorganisms. Lipase from $R$. miehei is an enzyme which hydrolyzes triglycerides specifically on sn- 1 and sn- 3 position, and hence, this enzyme works similarly to the lipases in human's gastrointestinal tract. Oils and fats are hydrolyzed enzymatically in the body by lipases found in the mouth (lingual lipase), stomach (gastric lipase), and intestine (pancreatic lipase). These lipases hydrolyze triglycerides at sn-1 and sn-3 position $[9,25,26]$.

\section{Effect of oils and HVCO on calcium and magnesium absorption}

Effect of some dietary oils and HVCO on fecal, urinary, serum calcium, and magnesium are presented in Tables 4 and 5.

Results show that the oils tested and HVCO cause significant increases in fecal calcium and magnesium and urinary calcium and magnesium, while significant decreases in serum calcium and magnesium compared to the control group. The highest to lowest fecal and urinary calcium are in rats given with palm oil, corn oil, VCO, and HVCO, respectively. The highest to lowest serum calcium

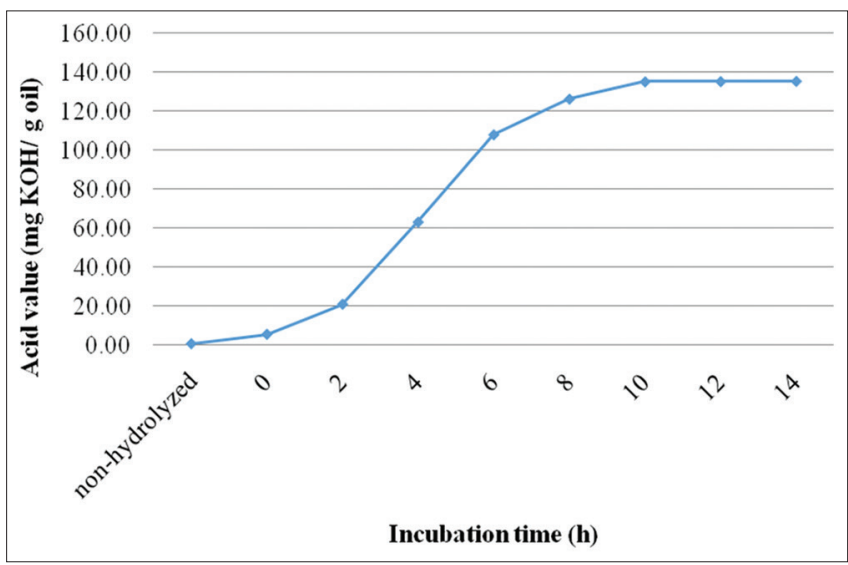

Fig. 1: The effect of incubation time on acid value of hydrolyzed virgin coconut oil 
and magnesium are found in rats given with HVCO, VCO, corn oil, and palm oil, respectively. Minerals absorption can be shown from the fecal, urinary, and serum minerals.

Elevation of fecal calcium and magnesium in groups fed on oils indicates the elevation of calcium and magnesium excretion which can be caused by disruption of calcium and magnesium absorption from the diet. Fatty acids, the product of hydrolyzed oil in gastrointestinal tract, react with calcium and magnesium from the diet and form salts of minerals and fatty acid. This salt is insoluble and hardly absorbed by the intestine mucous, therefore, it is excreted through the feces. Reduction of serum calcium and magnesium in rats given with oils can be explained by the elevation of calcium and magnesium excretion through the urine and feces $[5,8,27,28]$.
Effect of oils and HVCO on apparent minerals absorption, apparent minerals absorption ratio, and apparent minerals balance is shown in Tables 6 and 7 .

Results show that dietary oils given to rats cause significant decreases in minerals absorption compared to the control group. The highest to lowest minerals absorption in rats given with $2 \mathrm{ml} / \mathrm{kg}$ body weight of oils per day are $\mathrm{HVCO}, \mathrm{VCO}$, corn oil, and palm oil, respectively.

Difference between the effect of oils on calcium absorption and magnesium absorption is shown in Fig. 2.

As seen in Fig. 2, calcium absorption is higher than magnesium absorption in all groups including groups fed with and without oil.

Table 3: The effect of incubation time on acid value of HVCO

\begin{tabular}{|c|c|c|c|}
\hline Sample & Incubation time (h) & Acid value (mg KOH/g oil) $n=3$ & FFA $(\%) n=3$ \\
\hline Non-HVCO & - & $0.69 \pm 0.13^{a}$ & $0.25 \pm 0.05^{\mathrm{a}}$ \\
\hline \multirow[t]{7}{*}{ Enzymatically HVCO } & 0 & $5.52 \pm 0.29^{b}$ & $1.97 \pm 0.10^{\mathrm{b}}$ \\
\hline & 2 & $20.91 \pm 0.74^{\mathrm{c}}$ & $7.48 \pm 0.27^{c}$ \\
\hline & 4 & $63.02 \pm 0.67^{d}$ & $22.56 \pm 0.14^{\mathrm{d}}$ \\
\hline & 6 & $107.79 \pm 0.14^{\mathrm{e}}$ & $38.56 \pm 0.05^{\mathrm{e}}$ \\
\hline & 8 & $126.11 \pm 0.39^{f}$ & $45.33 \pm 1.82^{\mathrm{f}}$ \\
\hline & 10 & $134.96 \pm 0.23^{g}$ & $48.28 \pm 0.10^{\mathrm{g}}$ \\
\hline & 14 & $135.20 \pm 0.44^{\mathrm{g}}$ & $48.36 \pm 0.17^{g}$ \\
\hline
\end{tabular}

Means \pm SE in each column with different superscript letters differ significantly at $p<0.05$. HVCO: Hydrolyzed virgin coconut oil

Table 4: Effect of dietary oils and HVCO on fecal, urinary, and serum calcium

\begin{tabular}{llll}
\hline Treatment & Fecal Ca (mg/day) $\mathbf{n = 5}$ & Urinary Ca (mg/day) $\mathbf{n = 5}$ & Serum Ca (mg/dl)n=5 \\
\hline Control & $57.95 \pm 0.27^{\mathrm{a}}$ & $0.04 \pm 0.001^{\mathrm{a}}$ & $11.07 \pm 0.14^{\mathrm{a}}$ \\
VCO & $63.60 \pm 0.37^{\mathrm{b}}$ & $0.07 \pm 0.001^{\mathrm{b}}$ & $10.46 \pm 0.07^{\mathrm{b}}$ \\
Corn oil & $65.56 \pm 0.49^{\mathrm{c}}$ & $0.09 \pm 0.001^{\mathrm{c}}$ & $10.24 \pm 0.07^{\mathrm{c}}$ \\
Palm oil & $66.73 \pm 0.22^{\mathrm{d}}$ & $0.10 \pm 0.001^{\mathrm{d}}$ & $10.05 \pm 0.10^{\mathrm{d}}$ \\
HVCO & $60.91 \pm 0.43^{\mathrm{e}}$ & $0.05 \pm 0.001^{\mathrm{e}}$ & $10.59 \pm 0.07^{\mathrm{e}}$ \\
\hline
\end{tabular}

Means \pm SE in each column with different superscript letters differ significantly at $\mathrm{p}<0.05$, HVCO: Hydrolyzed virgin coconut oil

Table 5: Effect of dietary oils and HVCO on fecal, urinary, and serum magnesium

\begin{tabular}{llll}
\hline Treatment & Fecal Mg (mg/day) $\mathbf{n = 5}$ & Urinary $\mathbf{M g}(\mathbf{m g} / \mathbf{d a y}) \mathbf{n = 5}$ & Serum $\mathbf{M g}(\mathbf{m g} / \mathbf{d l}) \mathbf{n = 5}$ \\
\hline Control & $8.61 \pm 0.001^{\mathrm{a}}$ & $0.02 \pm 0.0001^{\mathrm{a}}$ & $4.19 \pm 0.03^{\mathrm{a}}$ \\
VCO & $9.72 \pm 0.03^{\mathrm{b}}$ & $0.03 \pm 0.0001^{\mathrm{b}}$ & $4.12 \pm 0.02^{\mathrm{b}}$ \\
Corn oil & $10.14 \pm 0.12^{\mathrm{c}}$ & $0.03 \pm 0.0004^{\mathrm{b}}$ & $3.97 \pm 0.04^{\mathrm{c}}$ \\
Palm oil & $10.54 \pm 0.04^{\mathrm{d}}$ & $0.03 \pm 0.0003^{\mathrm{b}}$ & $3.38 \pm 0.03^{\mathrm{d}}$ \\
HVCO & $9.39 \pm 0.04^{\mathrm{e}}$ & $0.03 \pm 0.0002^{\mathrm{b}}$ & $4.19 \pm 0.04^{\mathrm{e}}$ \\
\hline
\end{tabular}

Means $\pm S E$ in each column with different superscript letters differ significantly at $p<0.05$. HVCO: Hydrolyzed virgin coconut oil

Table 6: Effect of oils and HVCO on calcium absorption

\begin{tabular}{llll}
\hline Treatment & Apparent Ca absorption $(\mathbf{m g} /$ day) $\mathbf{n}=\mathbf{5}$ & Apparent Ca absorption ratio $(\mathbf{\%}) \mathbf{n = 5}$ & Apparent Ca balance $(\mathbf{m g} / \mathbf{d a y}) \mathbf{n = 5}$ \\
\hline Control & $62.25 \pm 0.27^{\mathrm{a}}$ & $51.79 \pm 0.22^{\mathrm{a}}$ & $62.21 \pm 0.27^{\mathrm{a}}$ \\
VCO & $56.60 \pm 0.37^{\mathrm{b}}$ & $47.09 \pm 0.31^{\mathrm{b}}$ & $56.53 \pm 0.37^{\mathrm{b}}$ \\
Corn oil & $54.64 \pm 0.46^{\mathrm{c}}$ & $45.46 \pm 0.38^{\mathrm{c}}$ & $54.55 \pm 0.46^{\mathrm{c}}$ \\
Palm oil & $53.47 \pm 0.22^{\mathrm{d}}$ & $44.48 \pm 0.18^{\mathrm{d}}$ & $53.37 \pm 0.22^{\mathrm{d}}$ \\
HVCO & $59.29 \pm 0.43^{\mathrm{e}}$ & $49.33 \pm 0.36^{\mathrm{e}}$ & $59.24 \pm 0.43^{\mathrm{e}}$ \\
\hline
\end{tabular}

Means $\pm S E$ in each column with different superscript letters differ significantly at $p<0.05$. HVCO: Hydrolyzed virgin coconut oil

Table 7: Effect of oils and HVCO on magnesium absorption

\begin{tabular}{llll}
\hline Treatment & Apparent Mg absorption (mg/day)n=5 & Apparent Mg absorption ratio (\%) $\mathbf{n = 5}$ & Apparent $\mathbf{M g}$ balance (mg/day)n=5 \\
\hline Control & $6.32 \pm 0.05^{\mathrm{a}}$ & $42.34 \pm 0.32^{\mathrm{a}}$ & $6.30 \pm 0.05^{\mathrm{a}}$ \\
VCO & $5.21 \pm 0.03^{\mathrm{b}}$ & $34.87 \pm 0.25^{\mathrm{b}}$ & $5.18 \pm 0.03^{\mathrm{b}}$ \\
Corn oil & $4.79 \pm 0.12^{\mathrm{c}}$ & $32.08 \pm 0.79^{\mathrm{c}}$ & $4.76 \pm 0.12^{\mathrm{c}}$ \\
Palm oil & $4.39 \pm 0.04^{\mathrm{d}}$ & $29.39 \pm 0.30^{\mathrm{d}}$ & $4.36 \pm 0.04^{\mathrm{d}}$ \\
HVCO & $5.54 \pm 0.04^{\mathrm{e}}$ & $37.11 \pm 0.26^{\mathrm{e}}$ & $5.51 \pm 0.04^{\mathrm{e}}$ \\
\hline
\end{tabular}

Means \pm SE in each column with different superscript letters differ significantly at $\mathrm{p}<0.05$. HVCO: Hydrolyzed virgin coconut oil 


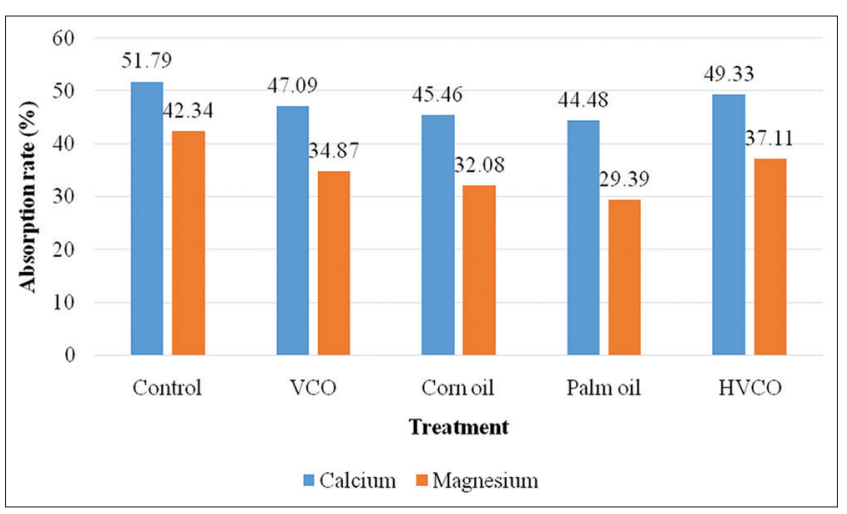

Fig. 2: Effect of oils on calcium and magnesium absorption

However, the effect of oils on magnesium absorption is more significant than on calcium absorption. The highest reduction of calcium and magnesium absorption is in the group fed on palm oil. The effect of palm oil on the reduction of calcium absorption is $7.41 \%$, while the reduction of magnesium absorption is $12.95 \%$.

From the results obtained in this study, treatment with dietary oils whether MCT, LCT, or hydrolyzed oil significantly decreases calcium and magnesium absorption compared to the control group (without oil). LCT (corn oil and palm oil) causes lower mineral absorption than MCT (VCO) and HVCO. Our results agreed with the previous study reported that MCT causes higher calcium absorption rather than LCT. These results may be possibly explained by the basis that LCT is hydrolyzed in the small intestine by pancreatic lipase and absorbed slowly through lymphatic system into the blood circulation. On the other hand, MCT is quickly hydrolyzed, begins in the mouth by lingual lipase, and continues in the stomach by gastric lipase then absorbed into the liver through portal vein, and hence, most hydrolyzed product do not reach the small intestine. Calcium and magnesium can react with LCFA generated from LCT oils hydrolysis to form insoluble mineral salts, which are not absorbed by intestine mucous, hence excreted through the feces $[9,10,29,30]$.

Concerning the effect of corn oil and palm oil on minerals absorption, palm oil causes lower minerals absorption than corn oil does. These results are in accordance to the previous studies reported. Calcium and magnesium absorption decreases significantly in animals fed on saturated fats than animals fed on unsaturated fats. Our results show that apparent calcium absorption in rats fed on corn oil and palm oil is 54.64 and $53.47 \mathrm{mg} /$ day, respectively. While apparent magnesium absorption in rats fed on corn oil and palm oil is 4.79 and $4.39 \mathrm{mg} /$ day, respectively. This may be caused by the difference between fatty acid composition in corn oil and palm oil. Corn oil contains unsaturated fatty acids (mainly linoleic acid) more than palm oil does, while palm oil contains more saturated fatty acids (mainly palmitic acid) $[13,14,31]$.

Non-HVCO causes lower calcium and magnesium absorption compared to HVCO because enzymatically HVCO is readily and quickly absorbed through portal vein, hence, decreasing its chance to react with calcium and magnesium in gastrointestinal tract to form the insoluble salt. It means that insoluble salt is very low or not produced, and hence, mineral absorption is not disrupted.

\section{CONCLUSION}

Optimum temperature and $\mathrm{pH}$ of $\mathrm{VCO}$ enzymatic hydrolysis using lipase from $R$. miehei are $50^{\circ} \mathrm{C}$ and $\mathrm{pH} 8$, respectively. The best incubation time for VCO enzymatic hydrolysis is after $10 \mathrm{~h}$. LCT (corn oil and palm oil) causes a significant decrease in calcium and magnesium absorption compared to MCT (VCO). HVCO causes a significant increase in calcium and magnesium absorption compared to non-HVCO.

\section{ACKNOWLEDGMENT}

This work was funded by the Ministry of Research, Technology and Higher Education of the Republic of Indonesia through "PMDSU" Research Grant 2016.

\section{REFERENCES}

1. Almatsier S. Prinsip Dasar Ilmu Gizi. Jakarta: PT. Gramedia Pustaka Utama; 2004.

2. Silalahi J. Dampak negatif air minum reverse osmosis (RO) terhadap kesehatan. J Indon Med Assoc 2014;64:215-7.

3. O'Dell BL, Sunde RA. Handbook of Nutritionally Essential Mineral Elements. New York: Marcel Dekker, Inc.; 1997.

4. World Health Organization. Calcium and Magnesium in Drinking-Water: Public Health and Significance. Spanyol, Geneva: World Health Organization; 2009.

5. Waldman T, Sarbaziha R, Merz NB, Shufelt C. Calcium supplements and cardiovascular disease: A review. Am J Lifestyle Med 2015;9:298-307.

6. Gogoi P, Kalita JC. Mineral content of some edible medicinally important leafy vegetables of Kamrup district of Assam, India. Int J Pharm Pharm Sci 2014;6:404-6.

7. Tai V, Leung W, Grey A, Reid IR, Bolland MJ. Calcium intake and bone mineral density: Systemtic review and meta-analysis. BMJ 2015;351:h4183.

8. Ensminger AH, Ensminger ME, Konlande JE, Robson JR. Foods and Nutrition Encyclopedia. $2^{\text {nd }}$ ed. USA: CRC Press; 1994.

9. Bohn, T. Dietary factors influencing magnesium absorption in humans. Curr Nutr Food Sci 2008;4:1-20.

10. Fife B. The Coconut Oil Miracle. New York: Penguin Group, Inc.; 2004.

11. Man YB, Manaf MA. Medium-chain triacylglycerols. In: Shahidi F, editor. Nutraceutical and Specialty Lipids and their Co-products. USA: Taylor \& Francis Group, LLC; 2006. p. 31-2.

12. Silalahi J, Nurbaya S. Komposisi, distribusi dan sifat aterogenik asam lemak dalam minyak kelapa dan kelapa sawit. J Indon Med Assoc 2011;61:453-7.

13. Rezq AA, Labib FA, Attia AE. Effect of some dietary oils and fats on serum lipid profile, calcium absorption and bone mineralization in mice. Pak J Nutr 2010;9:643-50.

14. Tadayyon B, Lutwak L. Interrelationship of triglycerides with calcium, magnesium and phosphorus in the rat. J Nutr 1968;97:246-54.

15. Elysa E, Harahap U, Silalahi J. Antibacterial activity of enzymatic hydrolisis of virgin coconut oil against Salmonella. Int J PharmTech Res 2014;6:589-99.

16. Silalahi J, Permata YM, Putra ED. Antibacterial activity of hydrolyzed virgin coconut oil. Asian J Pharm Clin Res 2014;7:90-4

17. Loung FS, Silalahi J, Suryanto D. Antibacterial activity of enzymatic hydrolized of virgin coconut oil and palm kernel oil against Staphylococcus aureus, Salmonella thypii and Escherichia coli. Int J PharmTech Res 2014;6:628-33.

18. Sihombing NT, Silalahi J, Suryanto D. Antibacterial activity of aqueous garlic (Allium sativum) extracts and virgin coconut oil and their combination against Bacillus cereus ATCC 14579 and Escherichia coli ATCC 8939. Int J ChemTech Res 2014;6:2774-82.

19. Ketaren S. Minyak dan Lemak Pangan. Jakarta: Universitas Indonesia; 2005.

20. Zenevicz MC, Jacques A, Furigo AF Jr, Oliveira JV, Oliveira D. Enzymatic hydrolysis of soybean and waste cooking oils under ultrasound system. Ind Crops Prod 2016;80:235-41.

21. Egba SI, Ugwu CE, Osuocha C. Effect of some dietary lipids administration on the levels of some serum minerals in wistar albino rats. Cibtech J Zool 2015;4:6-12.

22. Willis JB. Determination of calcium and magnesium in urine by atomic absorption spectroscopy. Anal Chem 1961;33:556-9.

23. Perkin E. Analytical Methods for Atomic Absorption Spectroscopy. USA: Perkin-Elmer Corporation; 1996.

24. Rodrigues RC, Fernandez-Lafuente R. Lipase from rhizomucor miehei as a biocatalyst in fats and oils modification. J Mol Catal B Enzym 2010;66:15-32.

25. Sivaraj R, Suji M, Priya SV. Optimization of lipase production from different agroindustrial wastes by marine actinomycetes. Int J Pharm Pharm Sci 2014;6:292-4.

26. Roskoski R. Biochemistry. Philadelphia, PA: W.B. Saunders Company; 1996.

27. Rolfes SA, Pinna K, Whitney E. Understanding Normal and Clinical Nutrition. $8^{\text {th }}$ ed. USA: Wadsworth, Belmoth; 2009. 
28. Gropper SS, Smith JL, Groff JL. Advanced Nutrition and Human Metabolism. $5^{\text {th }}$ ed. Australia: Belmont, Wadsworth Cengage Learning; 2009.

29. Haderslev KV, Jeppesen PB, Mortensen PB, Staun M. Absorption of calcium and magnesium in patients with intestinal resections treated with medium chain fatty acids. Gut 2000;46:819-23.
30. Chow CK. Fatty Acids in Foods and their Health Implications. $3^{\text {rd }}$ ed. USA: CRC Press; 2008.

31. Zambiazi RC, Przybylski R, Zambiazi MW, Mendonca CB. Fatty acid composition of vegetable oils and fats. B. CEPPA Curitiba 2007;25:111-20. 